\title{
PENGARUH BAURAN PROMOSI TERHADAP VOLUME PENJUALAN PADA PT. VIVA VICTORY ABADI
}

\author{
Komarudin \\ komar.udiyn@yahoo.com \\ Universitas Ahmad Dahlan \\ Hendro Setyono \\ hendro.setyono@yahoo.com \\ Universitas Ahmad Dahlan
}

\begin{abstract}
ABSTRAK
The purpose of this study was to determine the effect on promotion mix on volume sales PT Viva Victory Abadi. Results are expected to be a consideration for managers PT Viva Victory Abadi in determining the promotional mix effect on sales of property, as well as using some other variables of the promotion mix. The study was based on data usage all promotional costs incurred as well as the sale of the property from PT Viva Victory Abadi in the last two years. The data is then processed using multiple linear regression method in SPSS. The results obtained prove not the absence of significant promotional mix on volume sales of PT Viva Victory Abadi.
\end{abstract}

Keywords: Promotion Mix; Volume Sales.

\section{PENDAHULUAN}

Dalam perkembangan usaha dunia properti, Persaingan diantara perusahaan sejenis semakin ketat. Masing-masing perusahaan akan mempunyai strategi bauran promosi yang berbeda-beda, dimana strategi tersebut dipakai oleh perusahaan guna mencapai tujuan perusahaan di pasar. Dengan adanya keadaan pasar yang demikian, perusahaan harus pandai-pandai menyesuaikan diri agar dapat bertahan dalam persaingan. Salah satu unsur kegiatan yang menentukan keberhasilan suatu perusahaan adalah kegiatan promosi. Kegiatan promosi tidak hanya digunakan perusahaan untuk mengejar laba, tetapi juga lebih memperkenalkan produk jasa perusahaan kepada konsumen. (Rahardian, 2013).

Berhasil atau tidaknya suatu perusahaan untuk mengembangkan dirinya antara lain tergantung pada kemampuan perusahaan dalam mempromosikan dan memasarkan produk. Promosi berperan menggugah konsumen untuk yakin akan produk yang sesuai dengan selera dan keinginan dari konsumen. Penetapan bauran promosi (promotion mix) dari sebuah perusahaan merupakan strategi promosi guna mencapai tujuan promosi yang perusahaan inginkan dan sekaligus mencermati strategi promosi dari pesaingpesaing yang ada (Ekawati, 2014).

Pelaksanaan kegiatan promosi, perusahaan berharap dapat mendorong permintaan konsumen terhadap produk dan jasa yang ditawarkan, sehingga perusahaan dapat memadukan beberapa variabel, fokus dan arah strategi antar elemen bauran pemasaran yaitu produk (product), harga (price), tempat (place), promosi (promotion) dengan elemen bauran promosi yang meliputi periklanan (advertising), promosi penjualan (sales promotion), publisitas/hubungan dan pemasaran langsung (direct marketing), (Sinambela, 2008).

Selain itu juga diperlukan pemasaran yang baik. Dengan pemasaran produk yang baik maka akan dapat 
meningkatkan penjualan dan merebut pangsa pasar. Jika itu sudah terjadi maka dapat dipastikan perusahaan akan mendapatkan laba yang maksimal. Agar perusahaan tetap mampu bersaing dengan perusahaan lain yang mengeluarkan produk sejenis dan produk subsitusi, maka manajemen perusahaan harus mampu mengolah perusahaannya dengan baik. Supaya konsumen atau pelanggan yang ada tidak beralih kepada perusahaan lain . Perusahaan dituntut untuk lebih memahami segala kebutuhan dan keinginan konsumen atau perusahaan harus mampu menciptakan produk yang sesuai dengan kebutuhan konsumen. Selain itu juga diperlukan pemasaran yang baik (Supriyani, 2004).

Tujuan dari penelitian ini di antaranya: 1) untuk mengetahui apakah terdapat pengaruh antara variabel bauran promosi yaitu periklanan terhadap volume penjualan PT VIVA VICTORY ABADI,

2) untuk mengetahui apakah terdapat pengaruh secara parsial antara variabel bauran promosi yaitu promosi penjualan terhadap volume penjualan PT VIVA VICTORY ABADI, 3) untuk mengetahui apakah terdapat pengaruh secara parsial antara variabel bauran promosi yaitu hubungan masyarakat terhadap volume penjualan PT VIVA VICTORY ABADI, 4) untuk mengetahui apakah terdapat pengaruh secara parsial antara variabel bauran promosi yaitu penjualan pribadi terhadap volume penjualan PT VIVA VICTORY ABADI, 5) untuk mengetahui apakah terdapat pengaruh secara parsial antara variabel bauran promosi yaitu pemasaran langsung terhadap volume penjualan PT VIVA VICTORY ABADI dan 6) untuk mengetahui apakah bauran promosi secara bersama-sama berpengaruh terhadap volume penjualan PT. VIVA VICTORY ABADI.

\section{REVIEW LITERATUR DAN HIPOTESIS}

\section{Landasan Teori}

1. Manajemen Pemasaran

Manajemen pemasaran menurut (Kotler, 2007) pemasaran sebagai seni dan ilmu memilih pasar sasaran dan mendapatkan, menjaga, dan menumbuhkan pelanggan dengan menciptakan, menyerahkan dan mengkomunikasikan nilai pelanggan yang unggul.

\section{Bauran Pemasaran}

Menurut (Lupiyoadi, 2006), bauran pemasaran merupakan alat bagi pemasar yang terdiri atas berbagai unsur suatu program pemasaran yang perlu dipertimbangkan agar implementasi strategi pemasaran dan positioning yang ditetapkan dapat berjalan sukses. Ada empat inti bauran pemasaran, yaitu: Product, Price, Place, dan Promotion. Tetapi kemudian ditambah lagi dengan People, Process, dan Customer Service.

\section{Penjualan}

Penjualan menurut (Basuswasta, 2001) merupakan ilmu dan seni mempengaruhi pribadi yang dilakukan oleh penjual untuk mengajak orang lain agar bersedia membeli barang atau jasa yang disewakan.

\section{Penelitian Terdahulu}

Sinambela (2008) dalam penilitiannya yang berjudul "PENGARUH BAURAN PROMOSI TERHADAP PENINGKATAN VOLUME PENJUALAN PADA PT AQUASOLVE SANARIA". Berdasarkan penelitian tersebut variabel indepeden dalam penelitian ini adalah bauran promosi (periklanan, promosi penjualan, publisitas, penjualan pribadi, dan pemasaran langsung) dan variabel dependennya yaitu penjualan (hasil penjualan) dengan 
hasil bahwa bauran promosi berpengaruh secara positif terhadap peningkatan volume penjualan. Pengujuan ini dilakukan dengan menggunakan analisis regresi linier berganda diperoleh koefisien determinasi sebesar 0,599. Hal ini menunjukan bahwa terdapat pengaruh positif dan kuat antara bauran promosi terhadap peningkatan volume penjualan.

Ekawati (2014) dalam penilitiannya yang berjudul "PENGARUH PROMOTION MIX TERHADAP VOLUME PENJUALAN MOBIL DAIHATSU XENIA DI SURABAYA". Berdasarkan penelitian tersebut, Koefisien regresi variabel biaya promotion mix sebesar 0,00000036 menunjukkan bahwa biaya promotion mix berpengaruh positif terhadap volume penjualan, hal ini berarti semakin tinggi biaya promotion mix, maka volume penjualan pada Daihatsu Xenia PT. Astra International, Tbk-DSO Cabang Surabaya Waru akan meningkat. Hal ini dapat dilihat dari nilai $\mathrm{t}$ hitung sebesar 6.423 dengan nilai signifikansi sebesar 0,000 lebih kecil dari 0,05, maka H0 ditolak dan $\mathrm{H} 1$ diterima. Hasil perhitungan menurut metode model regresi mengatakan bahwa terdapat pengaruh yang signifikan antara variabel-variabel yang ada pada promotion mix terhadap volume penjualan Daihatsu Xenia PT. Astra International, Tbk - DSO Cabang Surabaya Waru. Hal ini dapat dilihat dari nilai korelasi (R) sebesar 0,740. Sedangkan nilai koefisien determinasi ( $\mathrm{R}$ Square) sebesar 0,548 menunjukkan bahwa variasi biaya promotion mix mampu menjelaskan variasi volume penjualan sebesar $54,8 \%$ terhadap volume penjualan Daihatsu Xenia PT. Astra International, Tbk-DSO Cabang Surabaya Waru.

Rahadian (2013) dalam penilitiannya yang berjudul "PENGARUH BAURAN PROMOSI TERHADAP PENINGKATAN PENJUALAN KAMAR DI HOTEL BENUA BANDUNG". Berdasarkan penelitian tersebut diketahui bahwa Selama lima tahun bauran promosi (periklanan, penjualan individu dan promosi penjualan) yang dilakukan oleh Hotel Benua Bandung menunjukkan persamaan regresi $\mathrm{Y}=-5.569 .500 .199+$ 106.217X. Hasil regresi ini menunjukkan pengaruhpositif variabel bauran promosi terhadap penjualan hotel Benua di Bandung. Koefisien korelasi (R2) sebesar 0,855 artinya variabel independen dapat menjelaskan sebesar $73,2 \%$ peningkatan volume penjualan.

\section{Hipotesis}

H1: Diduga ada pengaruh antara periklanan (X1) terhadap volume penjualan (Y) pada PT Viva Victory Abadi.

H2: Diduga ada pengaruh antara promosi penjualan (X2) terhadap penjualan (Y) pada PT Viva Victory Abadi.

H3: Diduga ada pengaruh antara hubungan masyarakat (X3) terhadap penjualan (Y) pada PT Viva Victory Abadi.

H4: Diduga ada pengaruh antara penjualan pribadi (X4) terhadap penjualan.

H5: Diduga ada pengaruh antara pemasaran langsung (X5) terhadap penjualan (Y) pada PT Viva Victory Abadi.

H6: Diduga ada pengaruh antara variabel bauran promosi (periklanan) (X1), (promosi penjualan) (X2), (hubungan masyarakat) (X3), (penjualan pribadi) (X4), dan (pemasaran langsung) (X5) secara bersama-sama terhadap volume penjualan (Y) pada PT Viva Victory Abadi. 


\section{METODE PENELITIAN}

\section{Populasi dan Sampel}

Populasi adalah kumpulan dari semua anggota yang diteliti (Algifari, 2013). Menurut (Sugiyono, 2010), populasi adalah wilayah generalisasi yang terdiri atas obyek/subyek yang mempunyai kualitas dan karakteristik tertentu yang ditetapkan oleh peneliti untuk dipelajari dan kemudian ditarik kesimpulan.

Dari teori-teori di atas dapat ditarik kesimpulan bahwa populasi yaitu kumpulan dari semua anggota atau wilayah generalisasi dari obyek yang memiliki kualitas atau karakteristik tertentu untuk dipelajari peneliti dan kemudian ditarik kesimpulan. Sehingga untuk memperoleh hasil penelitian yang diharapakan, peneliti mengambil populasi dalam penelitian ini adalah aktifitas laporan keuangan biaya peromosi, dan data laporan keuangan penjualan PT Viva Victory Abadi selama 2 tahun 2014-2015. PT Viva Victori Abadi merupakan transformasi dari victory property yang lahir pada 2013, tahun 2013 merupakan tahun bergriliyanya perushaan ini sehingga belum menggunakan laporan keuangan baku, namun pada januari 2014 perusahaan ini mulai menstandarisasi laporan keuangannya. Sehingga populasi data yang peneliti peroleh dari PT Viva Victory Abadi mulai tahun 2014-2015.

Sampel adalah kumpulan sebagian anggota dari obyek yang diteliti (Algifari, 2013). Menurut Sugiyono (2010), sampel adalah bagian dari jumlah dan karakteristik yang dimiliki oleh populasi tersebut. Bila populasi besar, dan peneliti tidak mungkin mempelajari semua yang ada pada populasi, misalnya karena keterbatasan dana, tenaga dan waktu, maka peneliti dapat menggunakan sampel yang diambil dari populasi itu. Apa yang dipelajari dari sampel itu, kesimpulanya akan dapat diberlakukan untuk populasi. Untuk itu sampel yang diambil dari populasi harus benar-benar representative (mewakili).

Dari teori-teori di atas dapat disimpulkan bahwa sampel adalah sebagian dari jumlah anggota atau karakteristik dari obyek atau populasi yang diteliti. Sampel dalam penelitian ini adalah aktifitas laporan keuangan biaya peromosi, dan data laporan keuangan penjualan PT Viva Victory Abadi selama 2 tahun 2014-2015, yang dianggap peneliti mampu menjelaskan pengaruhpengaruh bauran pemasaran terhadap volume penjualan.

\section{Definisi Operasional}

1. Variabel Independen Variabel bebas (variabel independen) dalam penelitian ini yaitu: periklanan, promosi penjualan, hubungan masyarakat, penjualan pribadi dan pemasaran langsung.

\section{Variabel Dependen}

Variabel terikat merupakan variabel yang dipengaruhi atau yang menjadi akibat, karena adanya variabel bebas. Variabel terikat (variabel dependen) dalam penelitian ini yaitu volume penjualan.

\section{Teknik Analisis Data}

\section{Analisis Regresi Berganda}

Regresi ganda berguna untuk mencapai pengaruh dua atau lebih variabel prediktor atau untuk mencari hubungan fungsional dua variabel prediktor atau lebih terhadap variabel kriteriumnya, atau untuk meramalkan dua prediktor atau lebih terhadap variabel kriteriumnya (Hartono, 2008). Sehingga dalam penelitian ini dapat dituliskan rumus persamaan regresinya: 
$\mathrm{Y}=\mathrm{a}+\mathrm{b} 1 \mathrm{X}_{1}+\mathrm{b} 2 \mathrm{X}_{2}+\mathrm{b} 3 \mathrm{X}_{3}+\mathrm{b} 4 \mathrm{X}_{4}+\mathrm{b} 5 \mathrm{X}_{5}+e$

Dimana:

$\mathrm{Y}=$ Total Volume penjualan (variabel dependen)

$\mathrm{a}=$ Konstanta

$\mathrm{b}=$ Koefisien Regresi

$\mathrm{X} 1$ = Biaya periklanan (variabel independen)

X2 = Biaya Promosi Penjualan (variabel independen)

X3 = Biaya Hubungan Masyarakat (variabel independen)

X4 = Biaya Penjualan Pribadi (variabel independen)

X5 = Biaya Penjualan Langsung (variabel independen)

$\mathrm{e}=$ Error

\section{Uji Hipotesis}

\section{Uji Parsial (Uji T)}

Uji t digunakan untuk mengetahui perbedaan nilai dari ratarata populasi dengan nilai rata-rata sampel yang digunakan sebagai pembanding (Adhilla, 2013).

Jika nilai signifikan $>0.05$, maka kesimpulannya menerima $\mathrm{HO}$ (hipotesis nol).

Jika nilai signifikan $<0.05$ maka kesimpulannya menerima Ha (hipotesis alternatif).

\section{Uji Simultan (Uji F)}

Uji $\mathrm{F}$ atau ANOVA (analysis of fariance) merupakan salah satu uji komparatif yang digunakan untuk menguji perbedaan ratarata data pada lebih dari dua kelompok (Adhilla, 2013).

\section{Uji Koefisien Determinasi}

Koefisien determinasi dapat digunakan sebagai petunjuk untuk mengetahui sejauh mana variabel independen dapat menjelaskan variasi variabel dependen. Besarnya koefisien determinasi adalah kuadrat dari koefisien korelasi. Misalnya suatu persamaan regresi mempunyai koefisien korelasi (r)-nya adalah 0,9 atau 90\% maka besarnya koefisien determinasi
(R2) persamaan regresi tersebut adalah 0,81 atau $81 \%$, sedangkan sisanya $19 \%$ dijelaskan (dipengaruhi) oleh variabel lain diluar persamaan regresi (model) tersebut (Algifari, 2013).

\section{HASIL PENELITIAN DAN PEMBAHASAN}

\section{Hasil Penelitian}

1. Hasil Uji Regresi Linier Berganda Hasil Regresi Berganda

\begin{tabular}{|c|c|c|c|c|}
\hline Model & B & Beta & t & Sig. \\
\hline Constanta & $2.173 \mathrm{E} 9$ & - & 1.247 & .259 \\
\hline Periklanan & 6075.738 & .418 & 1.014 & .350 \\
\hline Promosi penjualan & -2145.111 & -.335 & -.871 & .417 \\
\hline Hubungan masyarakat & 594.484 & .387 & .993 & .359 \\
\hline Penjualan pribadi & 562.770 & .150 & .409 & .697 \\
\hline Pemasaran langsung & -2223.732 & -.269 & -.640 & .546 \\
\hline
\end{tabular}

Dari output tersebut diperoleh persamaan regresi yaitu Total Volume Penjualan $=2.173+6075.738 \mathrm{X} 1-$ $2145.111 X 2+594.484 X 3+562.770 X 4$ $-2223.732 X 5$.

Berdasarkan persamaan di atas dapat diartikan bahwa:

a. Konstanta Nilai konstanta dari persamaan regresi ini sebesar 2.173 menunjukan besarnya volume penjualan jika pengaruh dari variabel-variabel periklanan (X1), promosi penjualan (X2), hubungan masyarakat (X3), penjualan pribadi (X4) dan pemasaran langsung (X5) besarnya adalah $2.173 \%$.

b. Koefisien variabel Periklanan sebesar 6075.738 menunjukan bahwa apabila biaya promosi naik satuan maka tingkat volume penjualan akan naik sebesar $6075.738 \%$, dalam hal ini faktor lain yang mempengaruhi volume penjualan dianggap konstanta.

c. Koefisien variabel promosi penjualan sebesar -2145.111 menunjukan bahwa apa bila biaya promosi naik satuan maka tingkat volume penjualan akan turun sebesar $2145.111 \%$, dalam hal ini faktor lain yang mempengaruhi 
volume penjualan dianggap konstanta.

d. Koefisien variabel hubungan masyarakat sebesar 594.484 menunjukan bahwa apabila biaya promosi naik satuan maka tingkat volume penjualan naik sebesar $594.484 \%$, dalam hal ini faktor lain yang mempengaruhi volume penjualan dianggap konstanta.

e. Koefisien variabel penjualan pribadi sebesar 562.770 menunjukan bahwa apabila biaya promosi naik satuan maka tingkat volume penjualan akan naik sebesar $562.770 \%$, dalam hal ini faktor lain yang mempengaruhi volume penjualan dianggap konstanta.

f. Koefisien variabel pemasaran langsung sebesar $\quad-2223.732$ menunjukan bahwa apa bila biaya promosi naik satuan maka tingkat volume penjualan akan turun sebesar $2223.732 \%$, dalam hal ini faktor lain yang mempengaruhi volume penjualan dianggap konstanta.

\section{Hasil Uji Parsial (Uji T)}

Uji Parsial

\begin{tabular}{|c|c|c|c|c|}
\hline Keterangan & $\begin{array}{c}\text { Alpha } \\
\mathbf{5 \%}\end{array}$ & & Sig & Kesimpulan \\
\hline Periklanan & 0.05 & $<$ & 0,350 & Tidak signifikan \\
\hline Promosi penjualan & 0.05 & $<$ & 0,147 & Tidak signifikan \\
\hline Hubungan masyarakat & 0.05 & $<$ & 0,359 & Tidak signifikan \\
\hline Penjualan pribadi & 0.05 & $<$ & 0,697 & Tidak signifikan \\
\hline Pemasaran langsung & 0.05 & $<$ & 0,546 & Tidak signifikan \\
\hline
\end{tabular}

Dari hasil uji $\mathrm{t}$ di atas dengan tingkat $\alpha=5 \%$ dapat disimpulkan bahwa secara parsial variabel bauran promosi yaitu priklanan, promosi penjualan hubungan masyarakat, penjualan pribadi, dan pemasaran langsung tidak terdapat perbedaan yang signifikan terhadap tingkat volume penjualan PT Viva Victory Abadi.
3. Hasil Uji Simultan (Uji F)

\begin{tabular}{|l|l|l|l|l|l|}
\hline Model & Sum of Squares & df & Mean Squares & F & Sig. \\
\hline Regression & $1.283 \mathrm{E} 19$ & 5 & $2.565 \mathrm{E} 18$ & .440 & $.807^{\mathrm{a}}$ \\
\hline Residual & $3.500 \mathrm{E} 19$ & 6 & $5.833 \mathrm{E} 18$ & & \\
\hline Total & $4.782 \mathrm{E} 19$ & 11 & & & \\
\hline
\end{tabular}

Dari hasil uji f pada tabel di atas diproleh nilai $\mathrm{F}$ hitung 0.440 dengan signifikasi sebesar 0.807. (0.807 > 0.05) maka dapat disimpulkan bahwa secara bersama-sama (simultan) variabel bauran promosi, periklanan, promosi penjulanan, hubungan masyarakat, penjualan pribadi, pemasaran langsung tidak berpengaruh signifikan terhadap volume penjualan PT. Viva Victory Abadi.

\section{Hasil Uji Koefisien Determinasi} Uji $\mathbf{R}^{2}$

\begin{tabular}{|c|c|c|}
\hline Model & R square & Adjusted R Square \\
\hline 1 & .268 & -.342 \\
\hline
\end{tabular}

Dari hasil pengujian ini maka diperoleh nilai $\mathrm{R}$ squaresebesar 0.268 artinya bahwa kemampuan variabel bauran promosi menjelaskan besarnya variasi dalam variabel penjualan adalah sebesar 26.8\%. sisahnya dijelaskan oleh faktor lain.

\section{KESIMPULAN DAN SARAN}

\section{Kesimpulan}

Berdasarkan hasil analisis data dan pembahasan yang dilakukan dalam penelitian ini, maka dapat diambil kesimpulan bahwa variabel bauran promosi yang meliputi periklanan, promosi penjualan, hubungan masyarakat, penjualan pribadi, dan pemasaran langsung terhadap volume penjualan tidak terdapat pengaruh yang signifikan secara parsial (sendiri-sendiri). Hal tersebut dapat dilihat dari output SPSS yang dihasilkan, dimana menunjukan bahwa semua indikator bauran promosi yaitu periklanan $(0.350$ $>0.05)$, penjualan $(0.417>0.05)$, hubungan masyarakat $(0.359>0.05)$, penjualan pribadi $(0.697>0.05)$, dan 
pemasaran langsung $(0.546>0.05)$. Nilai Sig lebih besar dari alpha 5\% (0.05). Uji F (simultan) menyatakan bahwa semua variabel tersebut tidak berpengaruh signifikan karna nilai f hitung 0.440 dengan signifikasi sebesar 0.807. (0.807 $>$ 0.05) maka dapat disimpulkan bahwa secara bersama-sama (simultan) variabel bauran promosi, periklanan, promosi penjulanan, hubungan masyarakat, penjualan pribadi, pemasaran langsung tidak berpengaruh signifikan terhadap volume penjualan PT. Viva Victory Abadi. Nilai koefisien determinasi dari hasil pengujian ini diperoleh nilai $\mathrm{R}$ square sebesar 0.268 artinya bahwa kemampuan variabel bauran promosi menjelaskan besarnya variasi dalam variabel penjualan adalah sebesar $26.8 \%$. sisahnya dijelaskan oleh faktor lain.

\section{Saran}

1. Bagi perusahaan untuk melengkapi data keuangan khususnya biaya aktifitas yang dikeluarkan perusahaan maupun aktifitas penjualan, tujuannya agar tidak terdapat kendala dikemudian hari dalam menerapkan strategi bauran promosi.

2. Sebelum menerapkan bauran promosi, terlebih dahulu memperhatikan posisi perusahaan dan faktor lain yang mempengaruhi volume penjualan diluar variabel bauran promosi.

3. Untuk kedepanya perusahaan bisa melihat strategi siklus hidup produk sebelum menerapkan bauran promosi untuk meningkatkan volume penjualan, karna saat ini PT. Viva Victory Abadi sedang berada di masa pertumbuhan. Dimana permintaan masih tinggi dan promosi tidak seagresif sebelumnya. Akan tetapi tidak menutup kemungkinan jika di tahun 2016 ini perusahaan mengalami pertumbuhan lebih cepat sehingga berada di posisi dewasa.

\section{DAFTAR PUSTAKA}

Adhilla, Fitroh, dkk. (2013). Modul Praktikum Satistik 2. Yogyakarta: Universitas Ahmad Dahlan.

Algifari. (2013). Statistika Deskriptif Plus Untuk Ekonomi Dan Bisnis. Yogyakarta: UPP STIM YKPN.

Basuswasta, D.H. (2006). Manajemen Pemasaran Modern. Edisi Kedua. Yogyakarta: Liberty.

Ekawati, Melati dan Christiani. (2014). Pengaruh Promotion Mix Terhadap Polume Penjualan Mobil Daihatsu Xenia Di Surabaya. Online. 18 Februari 2016, 22:45.

Hartono. (2008). SPSS 16.0 Analisis Data Stastitika dan Penelitian. Yogyakarta: Pustaka Pelajar.

Lupiyoadi, Rambat dan A. Hamdani. (2006). Manajemen Pemasaran Jasa. Jakarta: Salemba Empat.

Rahardian, D. Pratomo, A. (2013) Pengaruh Bauran Promosi Terhadap Peningkatan Penjualan Kamar Di Hotel Benua Bandung. Jurnal Binus Busines Review. Vol. 4 No. 2 November 2013: 776-790.

Sinambela, Sarton. Rohayani. (2008).

Pengaruh Bauran Promosi Terhadap Peningkatan Volume Penjualan Pada PT. Aquasolve Sanaria. Jurnal Manajemen Akutansi. Vol. IV No. 2 september 2008.

Sugiyono. (2010). Metode Penelitian Bisnis. Bandung: Alfabeta.

Supriyani, Emmy. (2004). Pengaruh Biaya Pelaksanaan Promosi Melalui Pameran Terhadap Tingkat Volume Penjualan Pada PT Astra Internasional Tbk Isuzu Cabang Bogor. Jurnal Ilmiah Ranggading. Vol. 4, No. 1, April 2004: 69-74. 
JURNAL FOKUS, Volume 6, Nomor 2 September 2016 